\title{
Symptomatic anomalous vascular ring with right aortic arch
}

\author{
Arun Sharma, ${ }^{1}$ Amarinder Singh Malhi, ${ }^{1}$ Sanjeev Kumar, ${ }^{1}$ Sadisu M Ma'aji ${ }^{2}$
}

${ }^{1}$ All India Institute of Medical Sciences, New Delhi, India ${ }^{2}$ Usmanu Danfodiyo University Sokoto, Nigeria, Sokoto, Nigeria

\section{Correspondence to} Dr Arun Sharma, drarungautam@gmail.com

Accepted 29 May 2016
CrossMark

\section{To cite: Sharma $A$,}

Malhi AS, Kumar $S$, et al BMJ Case Rep Published

online: [please include Day Month Year] doi:10.1136/ bcr-2016-216265

\section{DESCRIPTION}

A 3-month-old girl child presented with a history of respiratory distress, rapid breathing and mild cyanosis since birth. Auscultation revealed systolic murmur $(3 / 6)$ in the right parasternal and upper left parasternal area. ECG showed right axis deviation. Chest radiograph revealed mild cardiomegaly. Echocardiography was suggestive of double outlet right ventricle, ventricular septal defect (VSD) and pulmonary atresia. CT angiography revealed dextrocardia, VSD and pulmonary atresia with confluent, good-sized pulmonary arteries. The aorta was seen anterior to the pulmonary artery with right aortic arch. An aberrant left subclavian artery (LSCA) was seen with presence of large left persistent ductus arteriosus, connecting to the ostial left pulmonary artery forming an anomalous vascular ring, and causing lower tracheal compression (figure 1).
A symptomatic anomalous vascular ring with right aortic arch is very rare. A more common occurrence with right aortic arch is an aberrant LSCA followed by a mirror image branching pattern. ${ }^{1}$ Association with isolation of the subclavian artery is even rarer. Arch anomalies are usually associated with congenital heart diseases. A right aortic arch with a mirror image branching pattern is associated with tetralogy of Fallot, truncus arteriosus and VSD in 98\% of cases. ${ }^{2}$ However, associated congenital heart diseases are rarely seen with a right aortic arch and aberrant LSCA (in our case, association was seen with dextrocardia, malposed aorta and VSD-pulmonary atresia). ${ }^{2}$ Sometimes, these rings are symptomatic and may cause tracheal compression or dysphagia. ${ }^{3}$ Recognition and classification of these associated aortic arch anomalies are of prime importance in the management of congenital heart diseases.

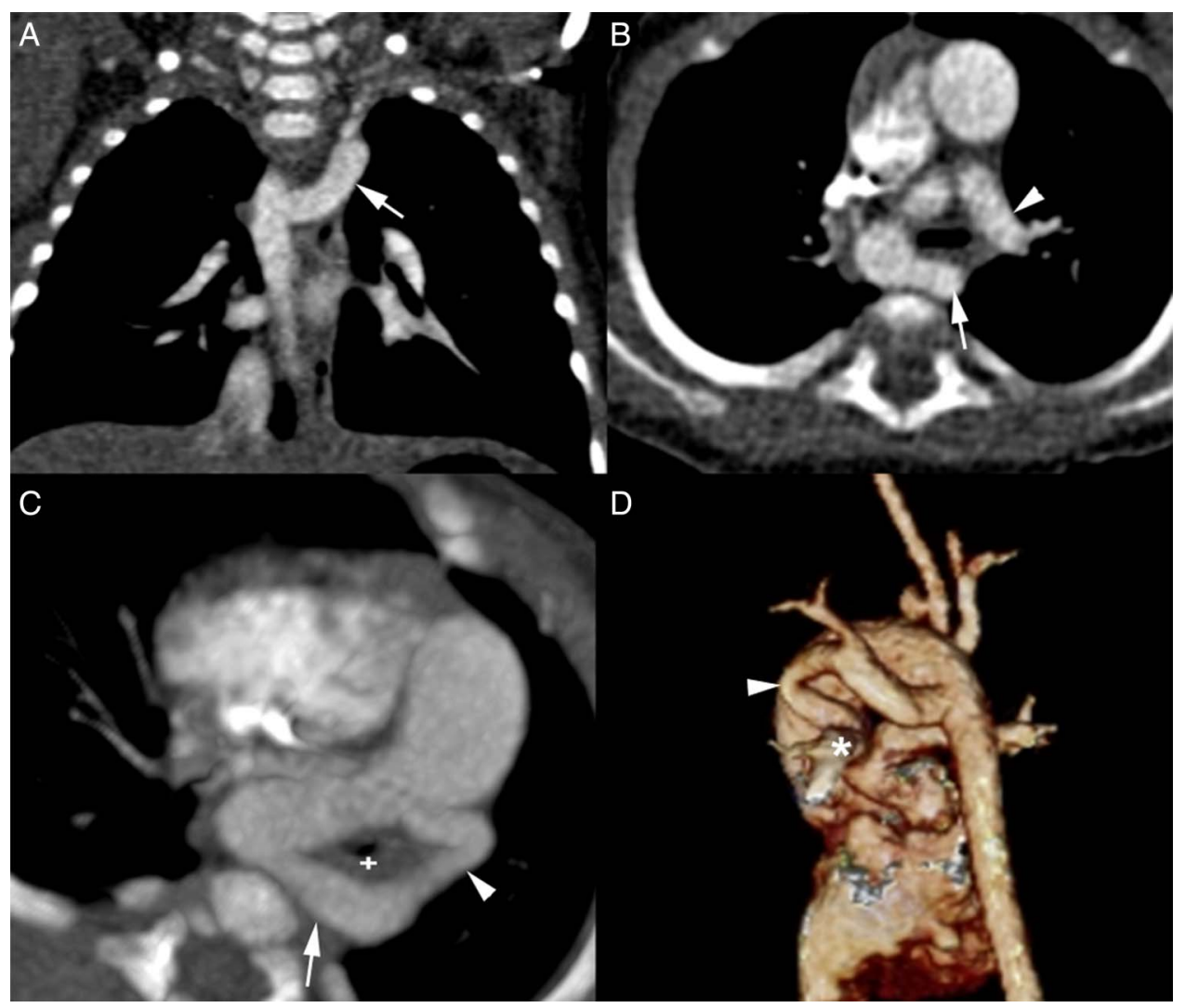

Figure 1 (A) Coronal CT image showing right arch with aberrant left subclavian artery (arrow). (B) Axial CT image showing left persistent ductus (arrowhead) and aberrant left subclavian artery (arrow) forming anomalous vascular ring and causing lower tracheal (anterior to+) compression as shown in (C) (reformatted image rotated to show the tortuous ductus). (D) Volume rendered image depicts the insertion of ductus (arrowhead) into ostial left pulmonary artery $\left(^{*}\right)$. 


\section{Learning points}

- Vascular rings are complex and pose a diagnostic challenge because of variable and non-specific clinical presentations, and associated congenital heart diseases.

- A symptomatic anomalous vascular ring with right aortic arch is very rare and associated congenital heart diseases are rarely seen with it.

- Recognition and classification of these associated aortic arch anomalies are of prime importance in the management of congenital heart diseases.
Competing interests None declared.

\section{Patient consent Obtained.}

Provenance and peer review Not commissioned; externally peer reviewed.

\section{REFERENCES}

1 Stewart JR, Kincaid OW, Edwards JE. An Atlas of vascular rings and related malformations of the aortic arch system. Illinois: Springfield, 1964:

12-131.

2 Yildirim A, Karabulut N, Doğan S, et al. Congenital thoracic arterial anomalies in adults: a CT overview. Diagn Interv Radiol 2011;17:352-62.

3 Berdon WE. Rings, slings, and other things: vascular compression of the infant trachea updated from the midcentury to the millennium-the legacy of Robert E. Gross, MD, and Edward B. D. Neuhauser, MD. Radiology 2000;216: 624-32.

Copyright 2016 BMJ Publishing Group. All rights reserved. For permission to reuse any of this content visit http://group.bmj.com/group/rights-licensing/permissions.

BMJ Case Report Fellows may re-use this article for personal use and teaching without any further permission.

Become a Fellow of BMJ Case Reports today and you can:

- Submit as many cases as you like

- Enjoy fast sympathetic peer review and rapid publication of accepted articles

- Access all the published articles

- Re-use any of the published material for personal use and teaching without further permission

For information on Institutional Fellowships contact consortiasales@bmjgroup.com

Visit casereports.bmj.com for more articles like this and to become a Fellow 